\title{
Arbuscular mycorrhizal fungal dynamics following change of land use from mature forest to Eucalyptus plantation ${ }^{\dagger}$
}

\author{
Chathuri Edirisinghe and Sumedha Madawala* \\ Department of Botany, Faculty of Science, University of Peardeniya, Peradeniya.
}

Revised: 16 January 2017; Accepted: 16 March 2017

\begin{abstract}
Change of arbuscular mycorrhizal fungi (AMF) dynamics following land use change was investigated. A study was carried out using four land use types viz., a mature forest (MF), a Eucalyptus plantation (EP: which was established after clearing mature forests in the area in 1980s) and two regenerating forests (Re: following clear-cut of Eucalyptus in 2005), where one is bordered by a Eucalyptus plantation (Re-EP) and the other bordered by a mature forest (Re-MF), located in the Intermediate Zone of Sri Lanka. Soil samples were collected from each land use type and the AMF spores were quantified and identified into morphotypes. Percentage AMF colonisation in fine roots was also quantified. Some basic soil parameters ( $\mathrm{pH}$, soil moisture, available $\mathrm{P}$ and total $\mathrm{C}$ ) were also tested. A total of 24,698; 16,379; 15,791 and 15,165 spores were recovered from MF, EP, Re-EP and Re-MF, respectively. The number of morphotypes was 14, 13, 11 and 9 in Re-EP, EP, MF and Re-MF, respectively. The MF showed the highest diversity index (0.970), followed by EP, Re-EP and Re-MF. The MF showed a significantly higher average number of spores $(2,058)$ compared to EP, Re-EP and Re-MF $(1,365 ; 1,316$ and 1,264 , respectively). Out of 19 morphotypes, 5 (26\%) were observed in all land use types, while 4 (21\%) were observed exclusively in Re-EP. Percentage root colonisation was significantly higher in MF $(\approx 70 \%)$ than in other land use types $(52-53 \%)$. The MF showed a higher soil moisture and total organic matter content than the rest of the study sites, with no significant difference in available P. The results indicate that the change of land use has clearly altered the abundance and composition of the AMF population.
\end{abstract}

Keywords: Arbuscular mycorrhizal fungi, Eucalyptus, Maragamuwa, regeneration, Sri Lanka.

\section{INTRODUCTION}

The conservation of the existing forest cover and restoration of degraded forests into natural woodlots have become important worldwide. During the restoration, the vegetation as well as the soil microbiota re-instate with time as the microbiota plays a crucial role in the process. Among the soil biota, arbuscular mycorrhizal fungi (AMF) play a decisive role forming symbiotic associations with higher plant roots, rendering mutualistic benefits to both parties. AMF improve soil health, as well as water and nutrient uptake by plants especially under stress conditions (De Souza \& Batista, 2004; Maherali \& Klironomos, 2007; Smith \& Read, 2008; van der Heijden et al., 2008). AMF are also known to enhance the survival of seedlings, and the growth of mature plants (Treseder, 2013; Davidson, 2015). Therefore, AMF play a significant role in determining the structure and composition of forest ecosystems as well as in their restoration processes following disturbances.

Soil disturbances can disrupt the existing mycorrhizal network that connects mycorrhizae and plants together (Sheng et al., 2012; Kohl et al., 2014). Once disturbed, the AMF network will take a long time to restore back to its original state. There are other factors such as host specificity, competition from other soil microbes and the availability of inocula, influencing the reinstatement of mycorrhizal associations and their abundance in

\footnotetext{
* Corresponding author (sumedha.madawala@gmail.com; (D) https://orcid.org/0000-0002-5140-4916)

$\dagger$ This work was presented at the $19^{\text {th }}$ International Forestry and Environment Symposium, Aliya Resort and Spa, Sigiriya, Sri Lanka. $24^{\text {th }}-25^{\text {th }}$ October 2014.
} 
disturbed sites (Parke et al., 1983). Furthermore, the role of native plants to promote AMF proliferation has also been highlighted in management interventions of degraded ecosystems (Tanner \& Gange, 2013). Rapid establishment of host plants may assist the fungal population to rebuild itself (Perry et al., 1987). Pioneers sharing the same species of mycorrhizal fungi as the native plants may act as reservoirs of fungal inoculum during plant establishment.

To evaluate the success of forest restoration, many studies have concentrated on measuring above-ground parameters with less focus on below-ground parameters including soil nutrients and soil biota (Ruiz-Jaen \& Aide, 2005). However, below-ground biological parameters are crucial in evaluating the success of forest restoration since they provide information on the resilience of the restored ecosystem (Wardle et al., 2004). The main aim of this study was to investigate how AMF population recovers during the process of forest regeneration. To achieve this, a regenerating forest (after clear-cutting Eucalyptus in 2005) was compared with a mature forest (representing the vegetation prior to the establishment of the Eucalyptus plantation) and an existing Eucalyptus plantation.

\section{METHODOLOGY}

\section{Study site and its history}

In early 1980s, the Ceylon Tobacco Company (CCT) established Eucalyptus camaldulensis and Eucalyptus grandis plantations in Naula in the Matale District after clearing mature forests (dry mixed evergreen forests with scattered deciduous trees) in the area (de Silva et al., 2013). However, the CCT decided to abandon these Eucalyptus plantations in 1990, and they were allowed to regenerate naturally. In 2005, as the natural succession was rather slow, some Eucalyptus plantations were clearcut in order to aid the natural forest regeneration process (Reed et al., 2009). Later, the site was declared as Maragamuwa Biodiversity Conservation Site (MBCS). The site is bordered by different land use types including a mature, intermediate zone forest, chena (shifting cultivation) lands, and Eucalyptus plantations etc. The area receives a mean annual rainfall of $1,750-2,500 \mathrm{~mm}$ with a mean annual temperature of $24-28^{\circ} \mathrm{C}$.

To conduct the study, four sites were selected: two sites of regenerating forests (after clear-cutting the Eucalyptus plantation in 2005), where one site is bordered by a mature forest (Re-MF), and the other by an existing Eucalyptus plantation (Re-EP); a mature forest (a dry mixed evergreen forest; MF); and a Eucalyptus

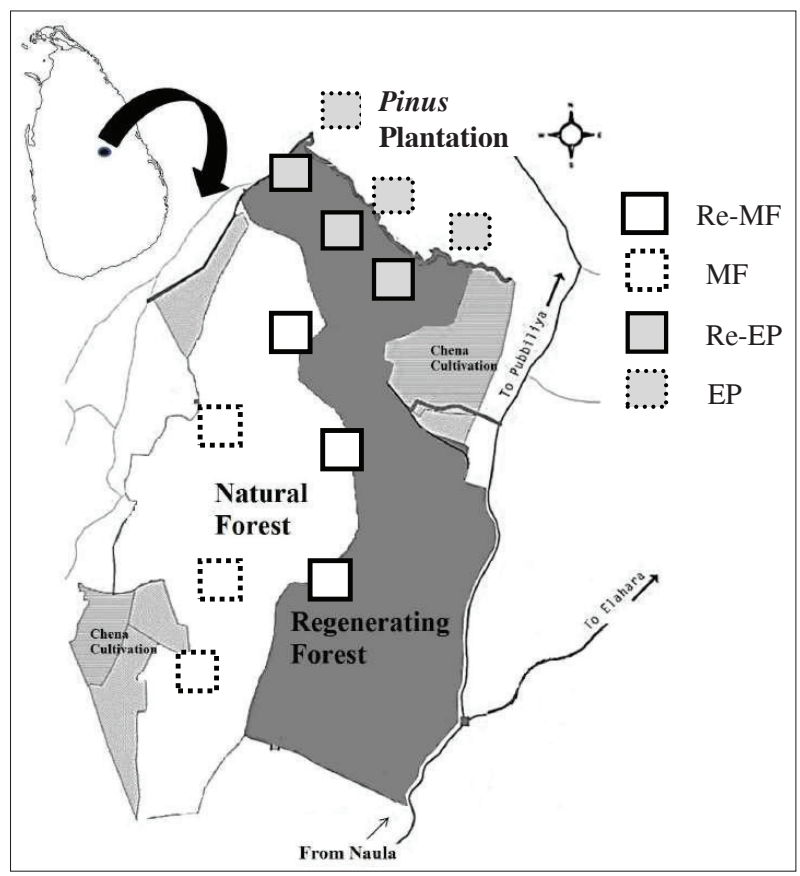

Figure 1: Map showing the three representative sites located in four different land use types including the mature forest (MF), regenerating forest closer to mature forest (Re-MF), regenerating forest closer to Eucalyptus plantation (Re-EP) and Eucalyptus plantation (EP). Main map was adopted from de Silva et al., 2013.

camaldulensis plantation (EP; $\approx 32$ years old; Figure 1). The two regenerating forest sites (Re-MF and Re-EP) were at a similar successional stage (they were initially abandoned in 1990 and later clear-cut in 2005). The four selected land use types provide an opportunity to quantify the AMF population dynamics following an anthropogenic disturbance to a mature forest. The four sites represent a chronosequence of land use types following establishment of Eucalyptus plantation after clearing mature forests in the area.

\section{Quantification of AMF spores}

Soil sampling was carried out once during the dry season in 2014. Four composite soil samples were collected randomly from a depth of $0-15 \mathrm{~cm}$ from 3 representative sites from each land use type (MF, Re-MF, Re-EP and EP), totalling 48 soil samples (4 land use types $\times 3$ blocks $\times 4$ samples $=48$ samples). AMF spores were quantified using the wet sieving and decanting method described by Brundrett (1995). Spores were categorised into 3 size classes using sieves with mesh sizes 250,63 and $45 \mu \mathrm{m}$. The isolated spores on filter papers were counted using a dissecting microscope. The spores were identified into different morphotypes depending on the 
spore characteristics including the colour, wall markings, appendages etc. With the spore numbers counted from different morphotypes, the abundance, spore richness, Shannon-Wiener diversity index and evenness were calculated (Magurran, 2009). Semi-permanent slides were prepared with spores of different morphotypes using polyvinyl alcohol-lacto-glycerol (PVLG) with Melzer's reagent for further identification using spore characteristics given in the INVAM website (http:// invam.wvu.edu).

\section{Assessing root colonisation}

Three composite soil cores were taken randomly (from a depth of $0-15 \mathrm{~cm}$ ) from each study site totalling 36 soil samples (4 land use types $\times 3$ blocks $\times 3$ samples $=36$ samples) to quantify AMF colonisation of roots. In the laboratory, live root samples were isolated after soaking the soil samples in water followed by wet sieving using a $0.25 \mathrm{~mm}$ sieve. Fine roots collected were analysed for root colonisation of AMF. Roots were cleared in $10 \%$ $\mathrm{KOH}$, then stained in $0.03 \% \mathrm{CBE}$ (chlorozol black E) and de-stained (if needed) in $50 \%$ glycerol (Brundett, 1995). Percentage root colonisation (\% root colonisation $=$ number of interceptions crossing AMF structures/total number of cortical cells) was calculated using the cross hair interception method as described by McGonigle in 1990.

\section{Soil chemical analysis}

Field-fresh soil samples were analysed for $\mathrm{pH}$ (soil:distilled water 1:4), gravimetric moisture content (\%) and available phosphorus (Olsen method). Total organic carbon (colourimetric method) and total nitrogen (Kjeldhal method) were also quantified (Anderson, 1993).

\section{Statistical analysis}

The data were analysed using general linear model (GLM) in Minitab version 16.0. Mean separations were done using Tukey's HSD ad-hoc test. The data set was checked for normal distribution using Anderson-Darling test prior to data analysis using parameteric methods.

\section{RESULTS AND DISCUSSION}

\section{Abundance, richness and composition of AMF spores}

According to the results obtained, the highest number of AMF spores were recorded in MF $(24,698)$ followed by EP $(16,379)$, Re-EP $(15,791)$ and Re-MF $(15,165)$ (Figure 2). The mean number of AMF spores showed significantly higher values in MF compared to the other land use types ( $\mathrm{p} \leq 0.05$; Figure 2$)$, indicating that during the conversion from a mature forest into a Eucalyptus plantation, the AMF population has declined significantly. However, no significant differences were observed in AMF spore abundance between the EP and regenerating forests (Re-EP or Re-MF).

The smallest spores $(<45 \mu \mathrm{m})$ dominated AMF spore counts in the MF compared to other land use types (Figure 3), while medium and large spore types did not show any significant difference between the land use types. The largest spores $(>250 \mu \mathrm{m})$ were the least prevalent in all land use types.

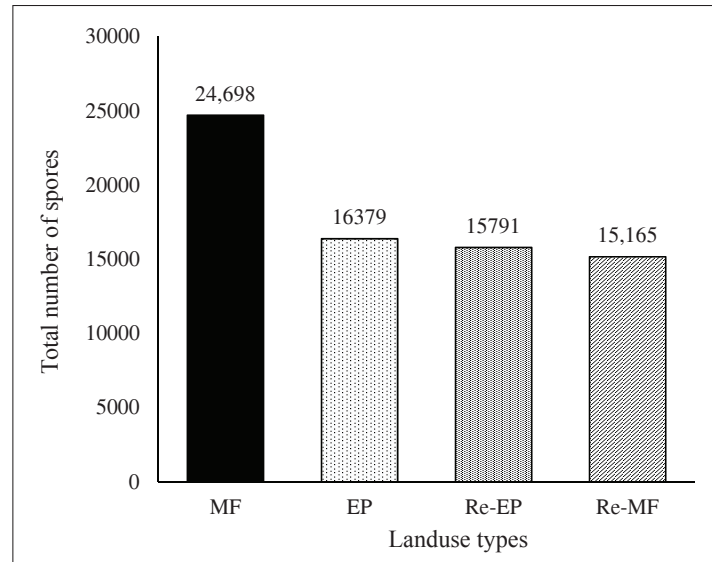

(a)

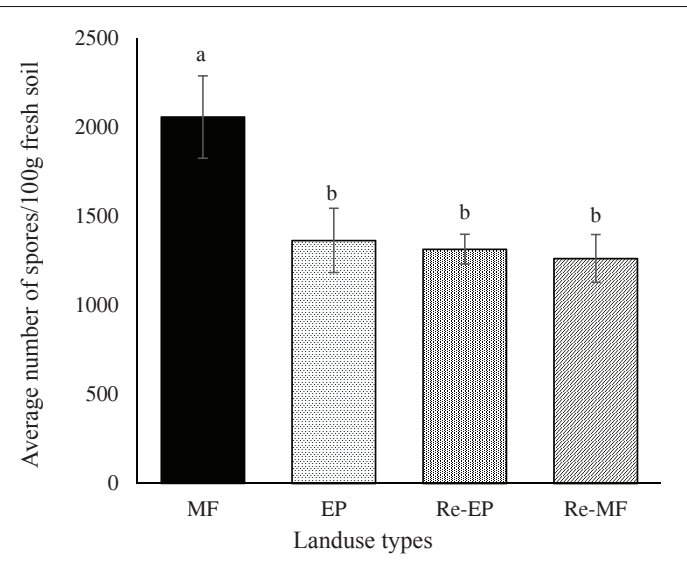

(b)

Figure 2: Total (a) and average number (b) of AMF spores between different land use types; mature forest (MF); Eucalyptus plantation (EP); regenerating forest closer to Eucalyptus plantation (Re-EP) and regenerating forest closer to a mature forest (Re-MF) located at Maragamuwa Biodiversity Conservation Site at Naula, Matale. 


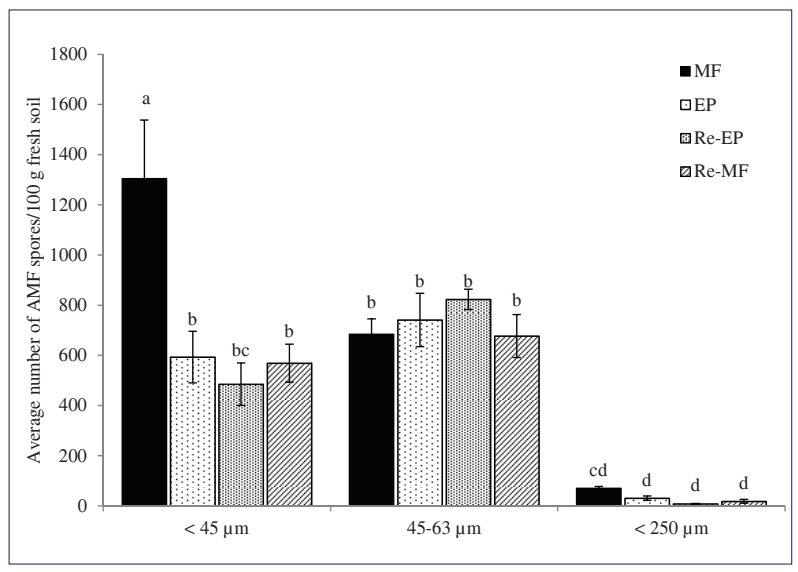

Figure 3: Average number of AMF spores (per $100 \mathrm{~g}$ soil) of different size categories (45, 63 and $>250 \mu \mathrm{m})$ among different land use types; mature forest (MF); Eucalyptus plantation (EP); regenerating forest closer to Eucalyptus plantation (Re-EP) and regenerating forest closer to a mature forest (Re-MF) located at Maragamuwa Biodiversity Conservation Site at Naula, Matale.

AMF spore richness was the highest in Re-EP (14) and the least in Re-MF (9), while MF and EP reported 11 and 13 spore morphotypes, respectively (Figure 6). However, no significant differences were observed in the average AMF spore richness among the four land use types (EP, Re-EP, Re-MF and MF) (Figure 4). Sturmer \& Berbara (2011) too observed no change in AMF richness when a pristine forest was converted into other land use types. In contrast, Correnho et al. (2014) stated that land degradation negatively affects not only the AMF abundance, but also the richness. The mediumsized AMF morphotypes $(63-250 \mu \mathrm{m})$ dominated the spore populations in all land use types, while the largest spores $(>250 \mu \mathrm{m})$ showed the least representations (Figure 5).

Out of the total 19 morphotypes recorded in the study, $5(\approx 26 \%)$ were observed in all four land use types and 4 morphotypes ( $\approx 21 \%$ ) were observed exclusively in the Re-EP. Among the AMF spores identified to their generic levels, Glomus, Acaulaspora and Gigaspora spp. were recorded in all four land use types while Scutellospora sp. was found only in Re-EP, indicating compositional differences between the land use types (Figure 5). A previous study suggested that although there are no differences in AMF richness between different habitats, AMF composition can vary (Hayman, 1983). Studies also suggest that the species composition of AMF communities is determined by the community structure of the vegetation (Wagg et al., 2014).

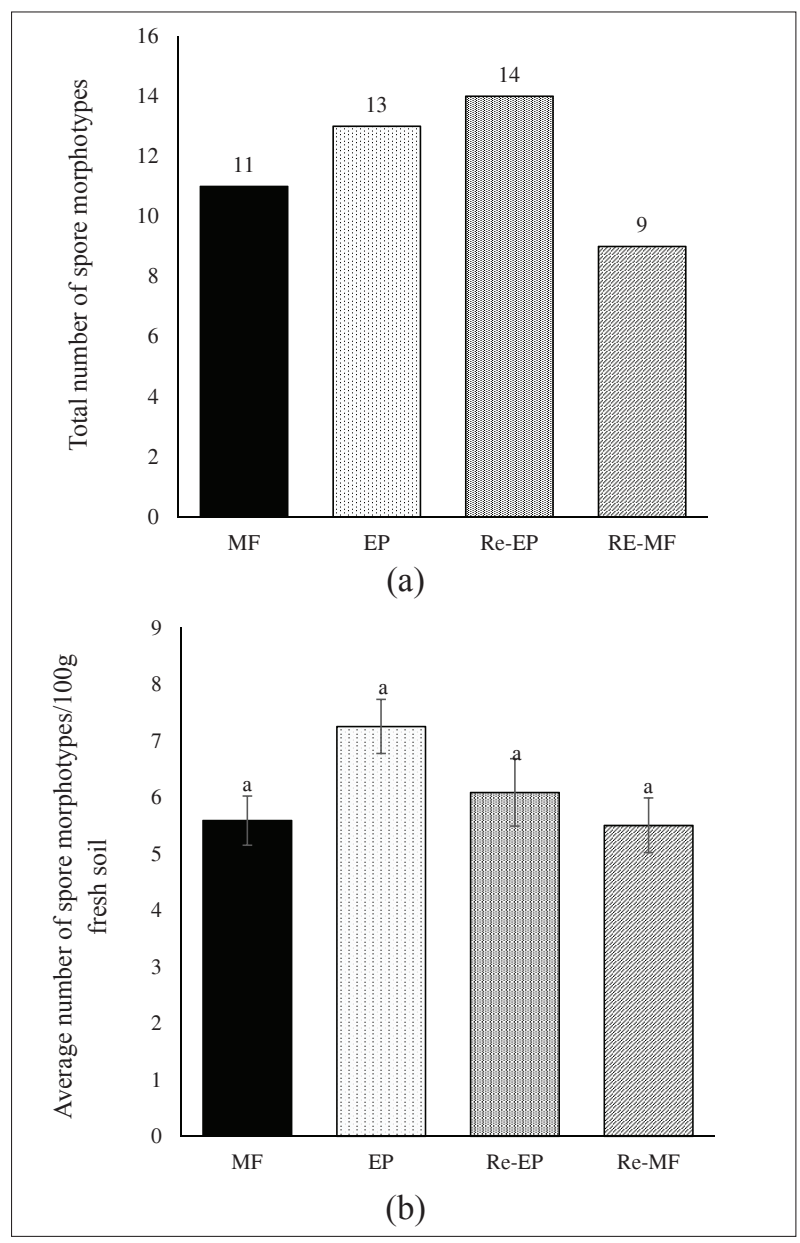

Figure 4: Total (a) and average number (per $100 \mathrm{~g}$ fresh soil) (b) of AMF spore morphotypes in different land use types; mature forest (MF); Eucalyptus plantation (EP); regenerating forest closer to Eucalyptus plantation (Re-EP) and regenerating forest closer to a mature forest (Re-MF) located at Maragamuwa Biodiversity Conservation Site at Naula, Matale.

The highest Shannon-Wiener (S-W) diversity index and evenness values were recorded in MF (0.969 and 0.404 , respectively), whereas the lowest S-W index and evenness values were documented in Re-MF (0.308) and Re-EP (0.129), respectively (Table 1). According to previous studies, no consistent shifts were recorded in the diversity of AMF during ecosystem development (Johnson et al., 1991; Pezzani et al., 2006; Sikes et al., 2012; Zangaro et al., 2012). However, Hayman (1983) noted that monoculture vegetation reduces the AMF diversity while it increases in landscapes with multiple species. A previous vegetation study carried out at the MBCS showed a higher diversity index $(>10 \mathrm{~cm} \mathrm{dbh})$ at the MF than that in Re-EP, Re-MF and EP (Alahakoon 


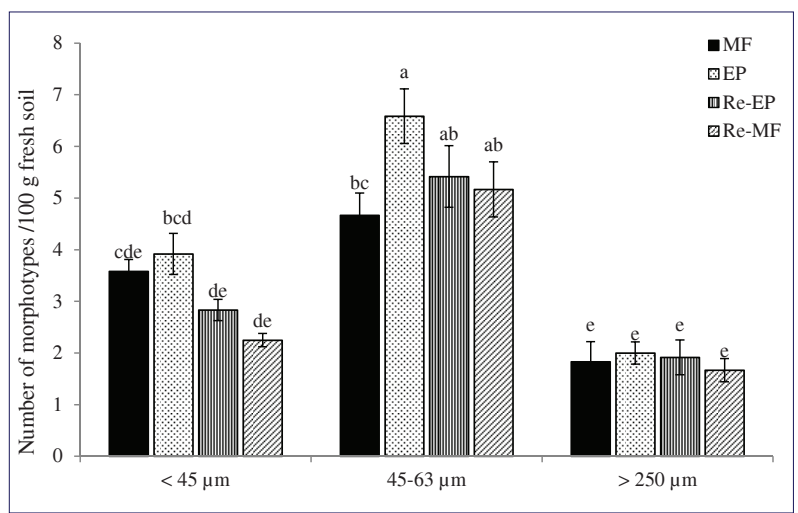

Figure 5: AMF spore richness (per $100 \mathrm{~g}$ fresh soil) among different land use types; mature forest (MF); Eucalyptus plantation (EP); regenerating forest closer to Eucalyptus plantation (Re-EP) and regenerating forest closer to a mature forest (Re-MF) located in Maragamuwa Biodiversity Conservation Site at Naula, Matale.

et al., 2006). Another study concluded that there are no significant differences in plant richness and abundance between the two regenerating forests, Re-EP and ReMF (unpublished data). The results of the present study therefore indicate that there is a positive relationship between the above-ground plant diversity and the diversity and abundance of below-ground AMF. In support of the present findings, Hiiesalu et al. (2014) had revealed that the AMF spore richness and abundance are positively correlated with plant species richness.
Table 1: Shannon-Weiner (S-W) diversity index and evenness values of AMF spores in different land use types located in and around Maragamuwa Biodiversity Conservation Site at Naula, Matale.

\begin{tabular}{lcc}
\hline Land use type & $\begin{array}{c}\text { S-W diversity } \\
\text { index }\end{array}$ & Evenness \\
\hline Mature forest (MF) & 0.969 & 0.404 \\
$\begin{array}{l}\text { Eucalyptus plantation (EP) } \\
\text { Regenerating forest bordered by }\end{array}$ & 0.468 & 0.182 \\
$\begin{array}{l}\text { Eucalyptus plantation (Re-EP) } \\
\text { Regenerating forest bordered by }\end{array}$ & 0.341 & 0.129 \\
a mature forest (Re-MF) & 0.308 & 0.140 \\
\hline
\end{tabular}

\section{Soil edaphic properties and root colonisation potential of AMF}

According to the soil analysis, soil moisture (\%) and organic C (\%) were significantly higher in the MF compared to other land use types (EP, Re-MF and Re-EP). All land use types showed near neutral soil $\mathrm{pH}$ values with significantly higher values at Re-EP. Soil $\mathrm{pH}$ values between 6 and 7.5 are optimum for plant growth and nutrient uptake (Hazelton \& Murphy, 2007). AMF spore abundance is reported to be closely related to soil type and soil pH (Gai \& Liu, 2003; Lekberg et al., 2011). According to Bivoko et al. (2013), AMF preferred nearneutral $\mathrm{pH}$ values and high organic matter content, while greater nutrient concentrations $(\mathrm{N}$ and $\mathrm{P})$ and high $\mathrm{pH}$

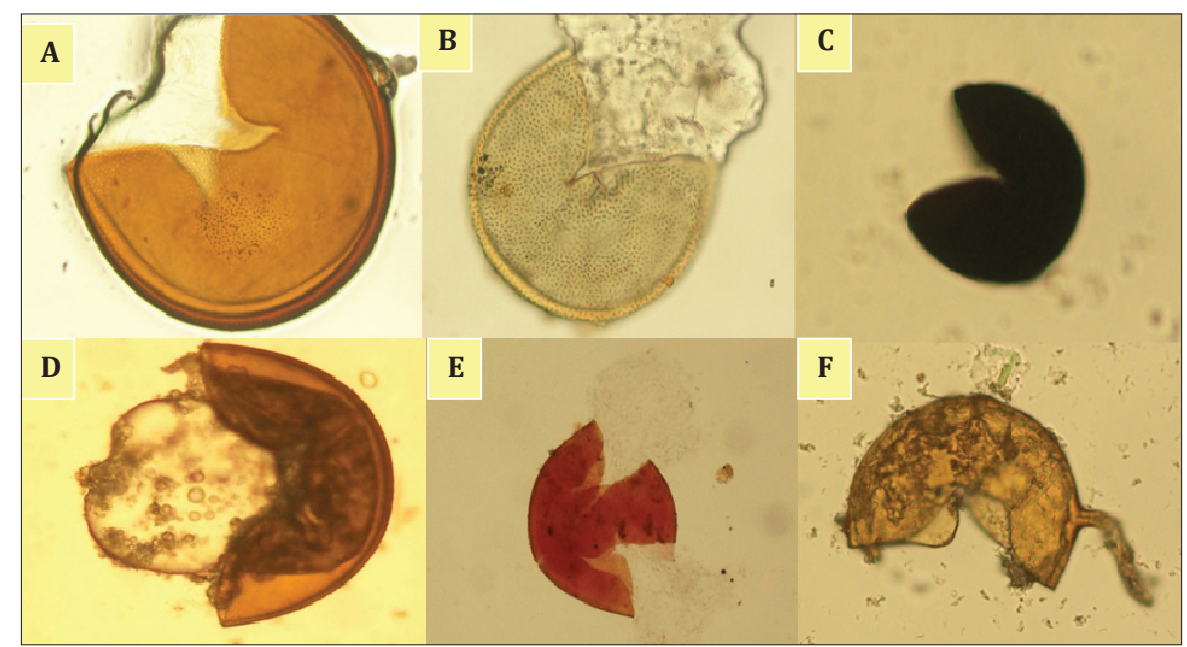

Figure 6: Some AMF morphotypes identified to their generic level during the study; $A$ and B: Acaulospora sp.; C: Glomus sp.; D: Scutellospora sp.; E: Gigaspora sp. and F: unidentified morphotype 
values can limit AMF development (Correnho et al., 2014). Margesin and Schinner (2005) also reported of a direct relationship between soil organic carbon content and the abundance and activity of soil microbes. However in the present study, available phosphorus showed no significant differences between the four land use types (Table 2). The percentage of AMF colonisation of fine roots $(<0.25 \mathrm{~mm})$ was higher $(\approx 70 \%)$ in $\mathrm{MF}$ compared to the other land use types ( $52-53 \%$ ), with no significant differences among them. A previous study has suggested that percentage root colonisation correlates with the AMF spore abundance and was influenced mainly by the host plant and soil texture (Sturmer \& Berbara, 2011). However, other studies suggest that AMF diversity mainly depend not only on the vegetation but also on the soil nutrient status (Kivlin et al., 2011).

Table 2: Some soil edaphic properties ( $\mathrm{pH}$, soil moisture, available $\mathrm{P}$ and total carbon) and root colonisation percentage of AMF in different land use types; MF (mature forest); EP (Eucalyptus plantation); ReEP (regenerating forest closer to Eucalyptus plantation) and Re-MF (regenerating forest closer to the mature forest) located in and around Maragamuwa Biodiversity Conservation Site at Naula, Matale.

\begin{tabular}{lccccc}
\hline Land use type & $\mathrm{pH}$ & Soil moisture (\%) & Available P $(\mu \mathrm{g} / \mathrm{g})$ & Total C (\%) & Root colonisation (\%) \\
\hline MF & $7.18^{\mathrm{b}}$ & $10.9^{\mathrm{a}}$ & $4.96^{\mathrm{a}}$ & $2.79^{\mathrm{a}}$ & $70.0^{\mathrm{a}}$ \\
Re-MF & $7.45^{\mathrm{b}}$ & $6.15^{\mathrm{b}}$ & $5.36^{\mathrm{a}}$ & $1.95^{\mathrm{b}}$ & $53.7^{\mathrm{b}}$ \\
Re-EP & $7.79^{\mathrm{a}}$ & $5.63^{\mathrm{b}}$ & $6.80^{\mathrm{a}}$ & $1.87^{\mathrm{b}}$ & $53.7^{\mathrm{b}}$ \\
EP & $7.10^{\mathrm{b}}$ & $5.49^{\mathrm{b}}$ & $8.40^{\mathrm{a}}$ & $1.46^{\mathrm{b}}$ & $52.5^{\mathrm{b}}$ \\
\hline
\end{tabular}

A strong positive correlation has been observed between soil organic carbon and soil microbial population and their activity (Singh et al., 2016). Higher soil moisture together with a greater organic $\mathrm{C}$ content in the MF may have facilitated a higher abundance of AMF and their colonisation potential in the present study.

According to this study, favourable soil conditions together with more diverse above-ground vegetation in the MF may have facilitated the higher abundance of AMF spores. Liang et al. (2015) also concluded that the diversity and composition of AMF are influenced by plant communities and soil nutrient properties. Other studies have also shown negative impacts on soil microbes when the natural forests are converted into plantations mainly due to decreases in soil organic carbon and necessary elements (Yu et al., 2012). A similar relationship was also observed in the present results indicating that land conversion from a mature forest into a Eucalyptus plantation has negatively influenced the composition and abundance of AMF. Even after a decade of allowing these Eucalyptus plantations to regenerate naturally, the AMF population is still trying to recover to its original status. Therefore, the results suggest that similar to the aboveground vegetation, below-ground AMF population also takes a considerable time to recover into its near original state. It is a well known fact that forest regeneration and the recovery of soil biota are simultaneous processes; hence it seems that the regenerating forests (Re-EP and Re-MF) at Naula are still in their early stages of recovery, at least in terms of AMF. Therefore, once disturbed, these intermediate forests may take long time to reinstate the vegetation as well as the soil biota to their near-original states.

\section{CONCLUSION}

A onetime sampling in a series of land use types (a regenerating Eucalyptus plantation, a mature forest and an untouched Eucalyptus plantation), which represent a chronosequence of events of a land conversion, from a mature forest to an Eucalyptus plantation has shown a drastic reduction of AMF abundance followed by a compositional change. However, the richness of AMF is unchanged.

\section{REFERENCES}

1. Alahakoon A.M.D.B., Siwananthawerl T. \& Ranawana K.B. (2006). Floristic diversity under an Eucalyptus camuldulensis plantation in Naula, Matale. The Sri Lanka Forester 29: 69 - 91.

2. Anderson J.M. (1993). Tropical Soil Biology and Fertility: A Handbook of Methods, $2^{\text {nd }}$ edition (eds. J.M. Anderson \& J.S.I. Ingram), p. 221. CAB International, Wallingford, Oxfordshire, UK.

3. Bivoko D.R., Nandjui J., Sery J.M.D., Fotso B., Amoa J.A., Kouadio M.S.A., Coulibaly S., Niamke S. \& Zeze A. (2013). Abundance and diversity of arbuscular mycorrhizal fungal (AMF) communities associated with cassava 
(Manihot esculenta Crantz) rhizosphere in Abengourou, East Côte d'Ivoire. Journal of Ecology and Natural Environment 5(11): 360 - 370.

DOI: https://doi.org/10.5897/JENE2013.0407

4. Brundrett M., Bougher N., Dell B., Grove T. \& Malajczuk N. (1995). Working with Mycorrhizas in Forestry and Agriculture. Australian Centre for International Agricultural Research (ACIAR), Canberra, Australia.

5. Correnho T., Hampell S., Homeir J. \& Wicker W. (2014). Nitrogen and phosphorus additions impact arbuscular mycorrhizal abundance and molecular diversity in a tropical montane forest. Microbial Ecology 22: 14 - 25.

6. Davidson B.E. (2015). Consequences of pre-inoculation with native arbuscular mycorrhizae on root colonization and survival of Wyoming big sagebrush (Artemisia tridentata ssp. wyomingensis) seedlings after transplanting. PhD thesis, Boise State University, Idaho, USA.

7. de Silva T., Ranawana K.B., Fernando S. \& Ellepola G. (2013). Comparison of avifaunal composition in a natural and a regenerating forest: towards using birds as ecological indicators. Ceylon Journal of Science (Biological Sciences) 42(2): $71-78$.

8. De Souza F.M. \& Batista J.L.F. (2004). Restoration of seasonal semideciduous forests in Brazil: influence of age and restoration design on forest structure. Forest Ecology and Management 191: 185 - 200.

DOI: https://doi.org/10.1016/j.foreco.2003.12.006

9. Gai J.P. \& Liu R.J. (2003). Effects of soil factors on AMF in the rhizosphere of wild plants. Chinese Journal of Applied Ecology 14: 18 - 22

10. Hayman D.S. (1983). The physiology of vesiculararbuscular endomycorrhizal symbiosis. Canadian Journal of Botany 61(3): $944-963$.

DOI: https://doi.org/10.1139/b83-105

11. Hazelton P. \& Murphy B. (2007). Interpreting Soil Test Results. CSIRO Publishing, Australia.

12. Hiiesalu I., Partel M., Davison J., Gerhold P., Metsis M., Moora M., Opik M., Vasar M., Zobel M. \& Wilson S.D. (2014). Species richness of arbuscular mycorrhizal fungi associations with grassland plant richness and biomass. New Phytologist 203: 233 - 244.

DOI: https://doi.org/10.1111/nph.12765

13. Johnson N.C., Zak D.R., Tilman D. \& Pfleger F.L. (1991). Dynamics of vesicular-arbuscular mycorrhizae during old field succession. Oecologia 86: 349 - 358 .

DOI: https://doi.org/10.1007/BF00317600

14. Kivilin S.N., Hawkesb C.V., Kathleen K. \& Tresedara K. (2011). Global diversity and distribution of arbuscular mycorrhizal fungi. Soil Biology and Biochemistry 43(11): $2294-2303$.

DOI: https://doi.org/10.1016/j.soilbio.2011.07.012

15. Kohl L., Oehl F. \& van der Heijden M.G.A. (2014). Agricultural practices indirectly infuence plant productivity and ecosystem services through effects on soil biota. Ecological Applications 24: $1842-1853$.

DOI: https://doi.org/10.1890/13-1821.1

16. Lekberg Y., Meadow J., Rohr J.R., Redecker D. \& Zabinski C.A. (2011). Importance of dispersal and thermal environment for mycorrhizal communities: lessons from Yellowstone National Park. Ecology 92: 1292 - 1302.

DOI: https://doi.org/10.1890/10-1516.1

17. Liang Y., He X., Chen C., Feng S., Liu L., Chen X., Zhao Z. \& Su Y. (2015). Influence of plant communities and soil properties during natural vegetation restoration on arbuscular mycorrhizal fungal communities in a karst region. Ecological Engineering 82: 57 - 65.

DOI: https://doi.org/10.1016/j.ecoleng.2015.04.089

18. Magurran A.E. (2009). Measuring Biological Diversity. Blackwell Publishing Limited, New Jersey, USA.

19. Maherali H. \& Klironomos J.N. (2007). Influence of phylogeny on fungal community assembly and ecosystem functioning. Science 316: $1746-1748$.

DOI: https://doi.org/10.1126/science.1143082

20. Margesin R. \& Schinner F. (2005). Manual for Soil Analysis: Monitoring and Assessing Soil Bioremediation (eds. R. Margesin \& F. Schinner), pp. 641. Springer-Verlag, Berlin-Heidelberg, Germany.

21. McGonigle T.P., Millers M.H., Evans D.G. \& Swan J.A. (1990). A new method which gives an objective measure of colonization of roots by vesicular-arbuscular mycorrhizal fungi. New Phytologist 115: 485 - 495.

DOI: https://doi.org/10.1111/j.1469-8137.1990.tb00476.x

22. Parke J.L., Linderman R.G. \& Trappe J.M. (1983). Effect of root zone temperature on ectomycorrhiza and vesicular-arbuscular mycorrhiza formation in disturbed and undisturbed soils of southwest Oregon. Canadian Journal of Forestry Research 13: 657 - 665.

DOI: https://doi.org/10.1139/x83-094

23. Perry D.A., Molina R. \& Amaranthus M.P. (1987). Mycorrhizae, mycorrhizospheres, and reforestation: current knowledge and research needs. Canadian Journal of Forest Research 17(8): 929 - 940.

DOI: https://doi.org/10.1139/x87-145

24. Pezzani F., Montana C. \& Guevara R. (2006). Associations between arbuscular mycorrhizal fungi and grasses in the successional context of a two-phase mosaic in the Chihuahuan Desert. Mycorrhiza 16: 285 - 295.

DOI: https://doi.org/10.1007/s00572-006-0044-y

25. Reed T., Ranawana K. \& Nanayakkara A. (2009). Methods tested and their costs to control regrowth of coppiced Eucalyptus camaldulensis in harvested plantations in Naula, Matale district, Sri Lanka. Ceylon Journal of Science (Biological Sciences) 38(2): $75-83$.

26. Ruiz-Jaen M.C. \& Aide T.M. (2005). Vegetation structure, species diversity, and ecosystem processes as measures of restoration success. Forest Ecology and Management 218: $159-173$.

DOI: https://doi.org/10.1016/j.foreco.2005.07.008

27. Sheng M., Lalande R., Hamel C., Ziadi N. \& Shi Y.C. (2012). Growth of corn roots and associated arbuscular mycorrhizae are affected by long-term tillage and phosphorus fertilization. Agronomy Journal 104: 1672 1678.

DOI: https://doi.org/10.2134/agronj2012.0153

28. Sikes B.A., Maherali H. \& Klironomos J.N. (2012). Arbuscular mycorrhizal fungal communities change among 
three stages of primary sand dune succession but do not alter plant growth. Oikos 121(11): $1791-1800$. DOI: https://doi.org/10.1111/j.1600-0706.2012.20160.x

29. Singh A.K., Rai A. \& Singh N. (2016). Effect of long term land use systems on fractions of glomalin and soil organic carbon in the Indo-Gangetic plain. Geoderma 277: 41 - 50. DOI: https://doi.org/10.1016/j.geoderma.2016.05.004

30. Smith S.E. \& Read D.J. (2008). Mycorrhizal Symbiosis. Academic Press, Cambridge, UK.

31. Sturmer F. \& Berbara R.L.L. (2011). Indegenous arbuscular mycorrhizae in areas with different successional stages at a tropical dry forest biome in Brazil. African Journal of Microbiology Research 5(12): $45-66$.

32. Tanner R.A. \& Gange A.C. (2013). The impact of two non-native plant species on native flora performance: potential implications for habitat restoration. Plant Ecology 214(3): 423 - 432 .

DOI: https://doi.org/10.1007/s11258-013-0179-9

33. Treseder K.K. (2013). Marschner review: the extent of mycorrhizal colonization of roots and its influence on plant growth and phosphorus content. Plant and Soil 371: $1-13$. DOI: https://doi.org/10.1007/s11104-013-1681-5

34. van der Heijden M.G.A., Bardgett R.D. \& van Straalen N.M. (2008). The unseen majority: soil microbes as drivers of plant diversity and productivity in terrestrial ecosystems. Ecology Letters 11: 296 - 310.

DOI: https://doi.org/10.1111/j.1461-0248.2007.01139.x

35. Wagg C., Bender C., Widmer S.F. \& van der Heijden M.G.A. (2014). Soil biodiversity and soil community composition determine ecosystem multifunctionality. Proceedings of the National Academy of Sciences 111(14): 5266 - 5270.

DOI: https://doi.org/10.1073/pnas.1320054111

36. Wardle D.A., Bardgett R.D., Klironomos J.N., Setälä H., van der Putten W.H. \& Wall D.H. (2004). Ecological linkages between aboveground and belowground biota. Science 304: 1629 - 1633. DOI: https://doi.org/10.1126/science.1094875

37. Yu Y., Shen W., Yin Y., Zhang J., Cai Z. \& Zhong W. (2012). Response of soil microbial diversity to land-use conversion of natural forests to plantations in a subtropical mountainous area of southern China. Soil Science and Plant Nutrition 58: 450 - 461.

DOI: https://doi.org/10.1080/00380768.2012.708645

38. Zangaro W., Alves R.A., Lescano L.E., Ansanelo A.P. \& Nogueira M.A. (2012). Investment in fine roots and arbuscular mycorrhizal fungi decrease during succession in three Brazilian ecosystems. Biotropica 44: $141-150$. DOI: https://doi.org/10.1111/j.1744-7429.2011.00781.x 